\title{
Bioconversion of agricultural waste and its efficient utilization in the hilly ecosystem of Northeast India
}

\author{
D. J. Rajkhowa ${ }^{1}$ A. K. Sarma ${ }^{1}$ P. N. Bhattacharyya ${ }^{2} \cdot$ K. Mahanta $^{3}$
}

Received: 18 April 2018 / Accepted: 25 February 2019 / Published online: 18 March 2019

(c) The Author(s) 2019

\begin{abstract}
Purpose A suitable strategy for bioconversion of agricultural waste into quality organic manure and its efficient utilization was assessed in the hilly ecosystem of Northeast India.

Methods Pits were dug in terrace lands and filled with chopped plant biomass (rice straw, maize stover and mixed weed biomass) with alternate layers of cow dung at 3:2 ratio. The treatment consisting of control (plant biomass + cow dung), plant biomass + cow dung + earthworm (Eisenia fetida) (with or without poly lining in the pit) and plant biomass + cow dung + earthworm + cellulose-degrading microorganism (Pseudomonas sp.) (with or without poly lining in the pit) was used for the bioconversion process.

Results Combined inoculation of E. fetida and Pseudomonas sp. with poly lining in the pit significantly enhanced compost recovery (29.8\%), cellulase activity (55.2\%) and the C:N ratio (1.9\%) as compared to control. Significant achievement in yield components and nutrient status in soil was observed after combined application of compost with $50 \%$ recommended dose of fertilizer.

Conclusion The current investigation established dual inoculation effect of E. fetida and Pseudomonas sp. with poly lining in the pit as a suitable technology for faster decomposition and effective bioconversion of agricultural waste into quality organic manure. A treatment imposed with such organic manure will be supportive in enhancing crop production as well as improving soil health.
\end{abstract}

Keywords Agricultural waste $\cdot$ Cellulose-degrading microorganism $\cdot$ Earthworm $\cdot$ Nutrient yield $\cdot$ Soil health

$\begin{array}{ll}\text { Abbreviations } \\ \text { CDM } & \text { Cellulose-degrading microorganism } \\ \text { CD } & \text { Cow dung } \\ \text { EW } & \text { Earthworm } \\ \text { PB } & \text { Plant biomass }\end{array}$

A. K. Sarma

anjan_icar@rediffmail.com

P. N. Bhattacharyya

pranabananda_01@rediffmail.com

K. Mahanta

kaberi.jorhat@gmail.com

1 Division of Natural Resource Management, ICAR Research Complex for NEH Region, Umiam, Meghalaya 793 103, India

2 Mycology and Microbiology Department, Tocklai Tea Research Institute, Tea Research Association, Jorhat, Assam 785 008, India

3 Department of Agronomy, Assam Agricultural University, Jorhat, Assam 785 013, India
WPL With poly lining

RDF Recommended dose of fertilizer

\section{Introduction}

Northeast India represents one of the richest biodiversity hot spot zones, worldwide. Agriculture in the northeastern hill region mostly subsists in nature with low input fertilizer utilization (N: $25.99 \mathrm{~kg} \mathrm{ha}^{-1}$; P: $7.11 \mathrm{~kg} \mathrm{ha}^{-1}$; $\mathrm{K}: 12.12 \mathrm{~kg} \mathrm{ha}^{-1}$ ) as against an all India average of $133.22 \mathrm{~kg} \mathrm{ha}^{-1}$ (Indian Fertilizer Scenario 2010) resulting in low productivity (Rajkhowa and Manoj-Kumar 2013). The marginal economy of the farmers is one of the limiting factors in the region. Moderate to steep sloppy land situation also makes it difficult to carry fertilizer and other bulky inputs like organic manure to the cultivated area. With a high intensity of rainfall followed by soil erosion, shifting cultivation leads to massive soil deterioration $\left(40.9 \mathrm{t} \mathrm{ha}^{-1}\right)$ with considerable nutrient loss (organic carbon: $702.9 \mathrm{~kg} \mathrm{ha}^{-1}$, P: $63.5 \mathrm{~kg} \mathrm{ha}^{-1}, \mathrm{~K}$ : 
$5.9 \mathrm{~kg} \mathrm{ha}^{-1}$ ) (Tripathi and Barik 2003). Thus, the demand for quality organic manure in the region has increased progressively. However, due to favorable climate and topography, the biomass production in the region is quite high (5-20 $\mathrm{tha}^{-1}$ ), which serves as an alternative source of energy for the development of sustainable agriculture (Moral et al. 2009). Abundance of crop residues and weed biomass in and around the farm lands of Northeast India (Hazarika et al. 2006) also serves as an excellent source of organic nutrients, if used properly. Development of appropriate and effective low-cost technologies for efficient bioconversion of on-farm and off-farm waste is, thus, urgent for restoring normal soil health and improvising plant nutrition.

Mahanta et al. (2012a) reported the kinetics in organic matter decomposition using an eco-friendly and sustainable approach, and presented opportunities to use non-chemicals against toxic chemical supplements. Singh and Jagadeesh (2009) reported the use of Eupatorium biomass as an alternative source of nutrients for groundnut cultivation through composting. Exploitation and utilization of earthworm as the potential decomposer of organic materials is considered as a suitable technology (Monroy et al. 2009; Molina et al. 2013), as the former is known to accelerate the quality organic manure production after modifying the physical, chemical and biological properties of soil. Mixing soil horizons by fragmentation, aeration and breakdown of organic matter in the soil, etc., are some of the key mechanisms associated with the mobilization of plant nutrients (Rousseau et al. 2010). Earthworm species are known for the production of plant growth regulators, vitamins, enzymes, etc., and thereby assist in normal functioning of the plant. Pathma and Sakthivel (2012) indicated earthworms as potent bioreactors in composting. Due to richness of nutrients and availability of beneficial microorganisms in the vermicompost, it has tremendous potential in enhancing soil fertility, crop yield and plant protection against significant pest and pathogen attack. Likewise, the cellulose-degrading microorganisms (CDMs) are also known as an efficient driver in biodegradation processes like enzyme digestion, nitrogen excrement and transport of immobilized nutrients in soil (Mahanta et al. 2012b). The microorganisms are known to produce enzymes like cellulase, endoglucanase, and cellobiohydrolase that work synergically to degrade cellulose. Kato et al. (2004) observed enhanced decomposition under the influence of CDM. Co-inoculation of beneficial microorganisms with earthworm is, nowadays, considered as a suitable strategy for plant biomass conversion into quality organic manure. Sinha (2009) demonstrated the dual role of microbial inoculants and earthworms in biochemical degradation of organic matter, although, the efficiency of decomposition may vary depending upon the nature of plant biomass used for bioconversion (Mahanta et al. 2012a). Bioconversion of organic materials into quality manure production for enhancing crop productivity and improving soil health is, thus, attaining popularity among the farmers, worldwide. In cognizance of the above, the present investigation was undertaken to develop a suitable strategy for bioconversion of agricultural waste into quality organic manure and its efficient utilization for increasing crop productivity and improving soil health in the hilly terrains of Northeast India.

\section{Materials and methods}

\section{Experimental plot selection}

The experiment was conducted at ICAR Research farm, Umiam, Meghalaya, India. Geographically, the area is situated at northern latitude $25^{\circ} 41.429^{\prime}$ and eastern longitude $91^{\circ} 55.341^{\prime}$ and with an altitude 3251 feet above the mean sea level (msl). Meteorological data pertaining to mean minimum and maximum temperature and relative humidity are presented in Fig. 1.

\section{Isolation and screening of effective CDM for bioconversion}

A culture-based approach was primarily used to isolate and characterize the CDMs from organic materials (vermicompost). $10.0 \mathrm{~g}$ air-dried and sieved sample was suspended in $100 \mathrm{ml}$ sterile distilled water (SDW) and incubated in an orbital shaking incubator at $28{ }^{\circ} \mathrm{C}$ with periodic shaking at $150 \mathrm{rpm}$ for $30 \mathrm{~min}$. Tenfold series dilutions were prepared, serially by taking $10 \mathrm{ml}$ of the soil suspension and dispensing it into $90 \mathrm{ml}$ of SDW. Soil particles were allowed to settle and the soil suspension of required dilution was inoculated on Petri plates containing basal salt medium (Mandels and Reese 1999) (ammonium sulfate $1.4 \mathrm{gl}^{-1}$, potassium dihydrogen phosphate $2.0 \mathrm{gl}^{-1}$, magnesium sulfate $0.3 \mathrm{gl}^{-1}$, calcium chloride $0.3 \mathrm{gl}^{-1}$, ferrous sulfate $0.005 \mathrm{gl}^{-1}$, manganese sulfate $0.0016 \mathrm{gl}^{-1}$, proteose peptone $1.0 \mathrm{gl}^{-1}$, urea $0.3 \mathrm{gl}^{-1}$, zinc chloride $0.0017 \mathrm{gl}^{-1}$, cellulose $10.0 \mathrm{gl}^{-1} ; \mathrm{pH}$ 5.3) supplemented with $1 \%$ carboxymethylcellulose (CMC). Petri plates were incubated up to 7 days at $37^{\circ} \mathrm{C}$. The bacteria able to utilize cellulose were isolated on cellulose agar media (potassium dihydrogen phosphate $0.5 \mathrm{gl}^{-1}$, magnesium sulfate $0.25 \mathrm{gl}^{-1}$, cellulose $2.0 \mathrm{gl}^{-1}$, agar $15.0 \mathrm{gl}^{-1}$, gelatine $2.0 \mathrm{gl}^{-1} ; \mathrm{pH}$ : 6.8). The bacteria with cellulosedegrading potential were confirmed by repeated streaking of the cultures on cellulose Congo red media (potassium dihydrogen phosphate $0.5 \mathrm{gl}^{-1}$, magnesium sulfate $0.25 \mathrm{gl}^{-1}$, cellulose $2.0 \mathrm{gl}^{-1}$, agar $15.0 \mathrm{gl}^{-1}$, Congo red $0.2 \mathrm{gl}^{-1}$, gelatine $2.0 \mathrm{gl}^{-1} ; \mathrm{pH}: 6.8$ ), where Congo red serves as an indicator (Gupta et al. 2012) of cellulose degraders. Discolouration of Congo red is considered as a positive test for the microbes (Lu et al. 2004). The bacteria were identified in accordance 
Fig. 1 Variation in mean minimum and maximum temperature $\left({ }^{\circ} \mathrm{C}\right)$ and relative humidity (\%) of the study area

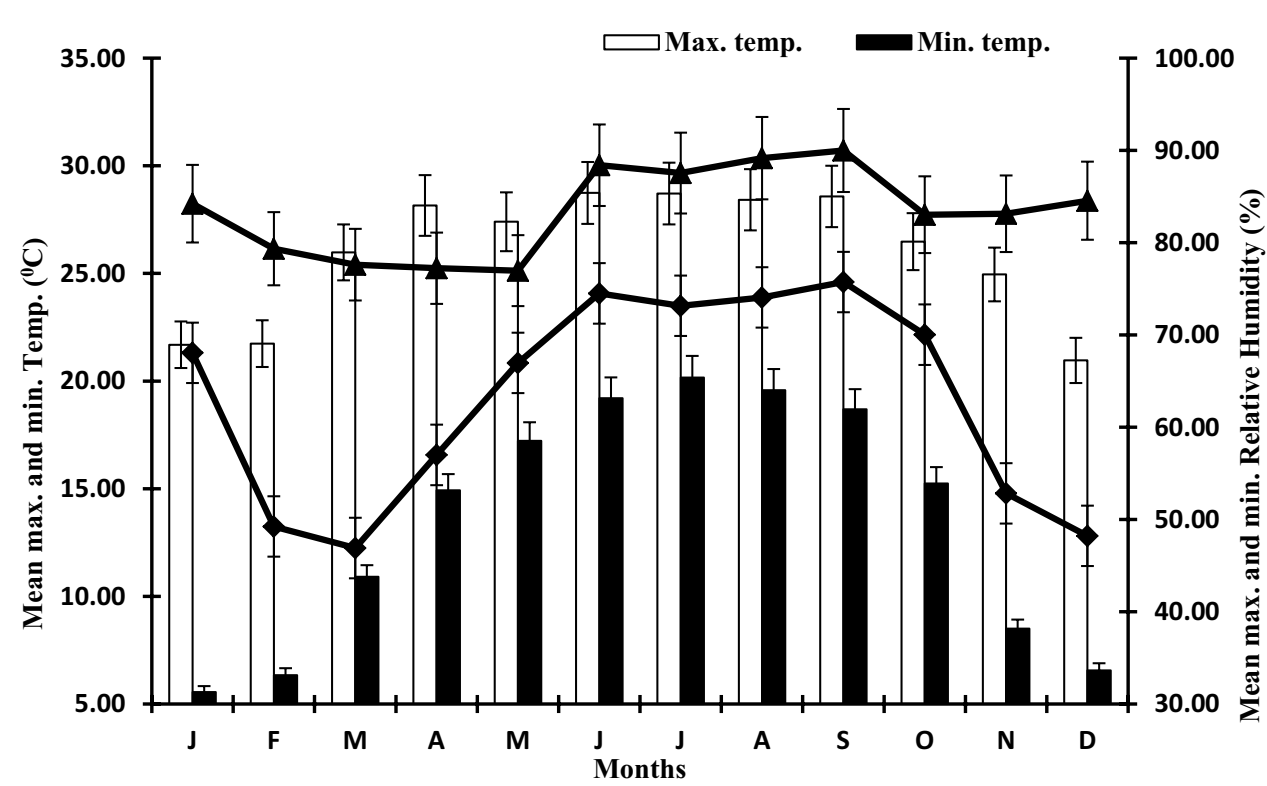

with Cappucino and Sherman (2004) and Holt et al. (1994). The quantitative estimation for the hydrolysis capacity (HC) of the cellulytic microbes was measured in accordance with standard protocols. The largest ratio was assumed to have highest potential. The microbial pathogenicity test was carried out using media like Eosin methylene blue (EMB) agar and MacConkey agar (MCA).

\section{Sampling of earthworm populations}

Earthworm collection was made during the morning hours in accordance with Tondoh and Lavelle (2005). Tropical Soil Biology and Fertility Programme (Anderson and Ingram 1993; Rajkhowa et al. 2015) was followed to sample the worm populations. Hand sorting and wet sieving method (Rajkhowa et al. 2015) was used for age-wise and specieswise segregation of the worms. Earthworms were washed with tap water and processed for taxonomic identification after supplementing with $4 \%$ formalin solution. The samples were identified at Zoological Survey of India (ZSI), Kolkata, India. All the earthworm species were numbered and compost suitability was observed manually. The sieving method was followed to calculate the potential of worms in composting (Raphael and Velmourougane 2012). A number of brick tanks were, thus, designed for treatment application. Treatments devoid of earthworm inoculation served as control. During the present investigation, 17 earthworm species belonging to 11 different genera and 6 families of the class Oligochaeta were sampled. Systematic enumeration of the identified earthworm species is presented in Table 1. Out of all the sampled earthworms, only Eisenia fetida showed maximum composting efficiency, therefore, the species was selected for further bioconversion process. Earthworm
Table 1 Systematic enumeration of earthworm species

\begin{tabular}{llll}
\hline Sl. no. & Earthworm species & Order & Family \\
\hline 1 & Amynthas alexandri & Haplotaxida & Megascolecidae \\
2 & Amynthas diffringens & Haplotaxida & Megascolecidae \\
3 & Dichogaster saliens & Haplotaxida & Ocnerodrilidae \\
4 & Drawida nepalensis & Moniligastridae & Moniligastridae \\
5 & Drawida sp. 1 & Moniligastridae & Moniligastridae \\
6 & Drawida sp. 2 & Haplotaxida & Ocnerodrilidae \\
7 & Eisenia fetida & Haplotaxida & Lumbricidae \\
8 & Eisenia sp. & Haplotaxida & Lumbricidae \\
9 & Eutyphoeus sp. & Haplotaxida & Ocnerodrilidae \\
10 & Glyphidrilus gangeticus & Haplotaxida & Almidae \\
11 & Gordiodrilus elegans & Haplotaxida & Ocnerodrilidae \\
12 & Lampito mauritii & Haplotaxida & Megascolecidae \\
13 & Metaphire posthuma & Haplotaxida & Megascolecidae \\
14 & Perionyx annandalei & Haplotaxida & Megascolecidae \\
15 & Pontoscolex corethrurus & Haplotaxida & Glossocolecidae \\
16 & Perionyx excavatus & Haplotaxida & Megascolecidae \\
17 & Perionyx sp. & Haplotaxida & Megascolecidae \\
\hline
\end{tabular}

biomass was determined using Edwards and Bohlen (1996) after drying the worms for $48 \mathrm{~h}$ on filter paper at $60{ }^{\circ} \mathrm{C}$.

\section{Experimental design}

Different plant biomasses such as rice straw, maize stover and weed biomass were collected and screened on the basis of their availability and abundance. A series of pits $(3 \times 1.5 \times 1 \mathrm{~m}$ size $)$ were dug in the terrace land situation (Fig. 2) to observe bioconversion. Before filling with plant biomass, the pits were plastered with mud. A modified 

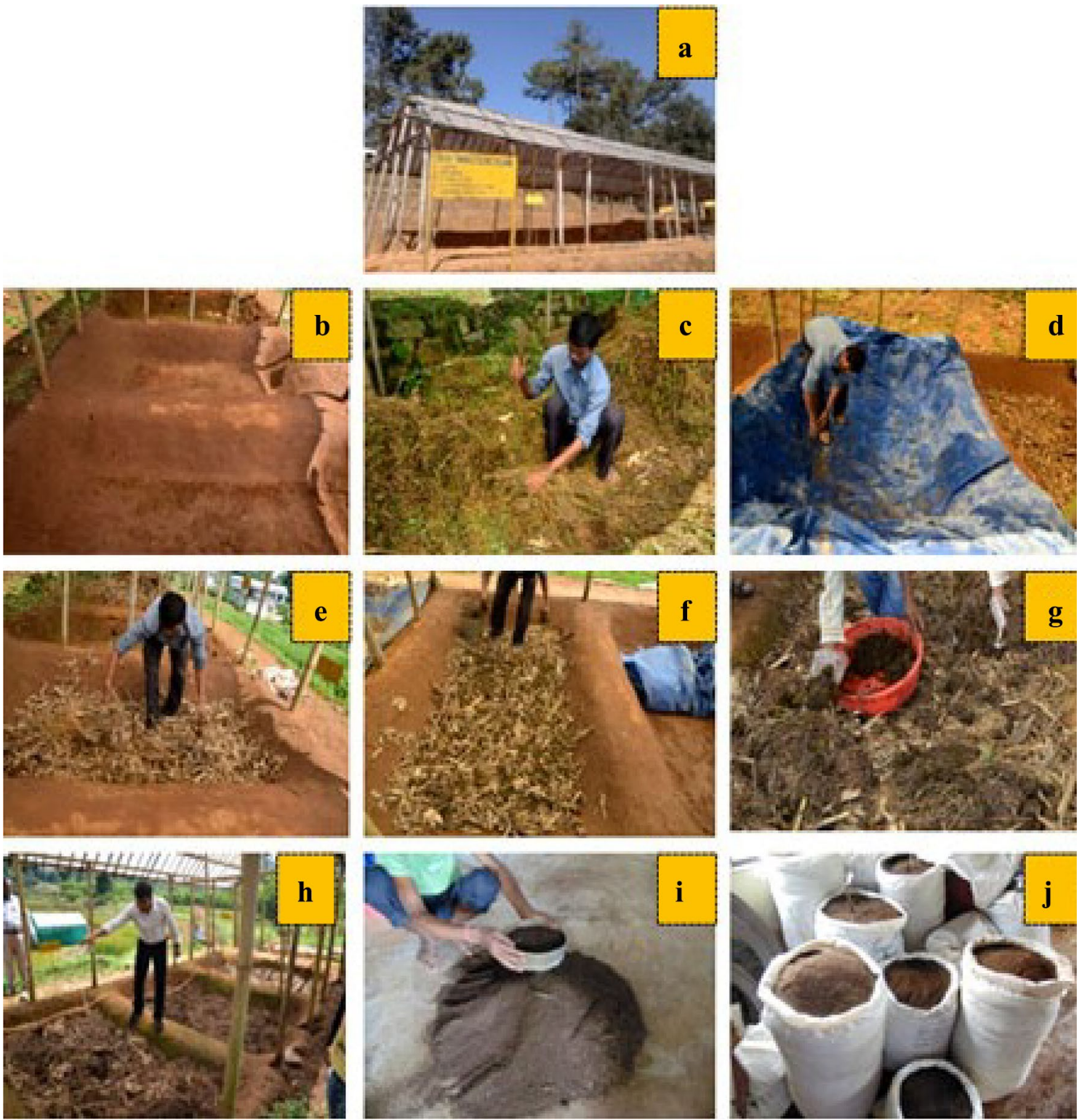

Fig. 2 Bioconversion of plant biomass into quality organic manure

protocol of Ansari (2010) was followed for biodung composting. Plant biomass was pre-digested through biodung compost technology and filled into the vermicomposting unit in a cyclic manner. Proper monitoring of temperature at regular intervals was made during composting. After every 15-20 days, the biodung compost was turned and later transferred to respective Vermitech units for composting (Fig. 2). Plant biomass (rice straw, maize stover, mixed weed biomass) was chopped $(2-3 \mathrm{~cm}$ size) and placed with alternate layer with cow dung at 3:2 ratio. Treatments, viz., control (plant biomass + cow dung), plant biomass + cow dung + earthworm (with poly lining), plant biomass + cow dung + earthworm (without poly lining), plant biomass + cow dung + earthworm + CDM (with poly lining) and plant biomass + cow dung + earthworm + CDM (without poly lining) were used for the bioconversion process. Five replicates were maintained for each treatment. Earthworm species (E. fetida) was mixed carefully in their respective treatments until the homogenous mixture was obtained. According to Rajkhowa and Borah (2008), $2.0 \mathrm{~kg}$ of earthworm is required per ton of dry plant biomass to obtain homogeneity.

In the present investigation, $120 \mathrm{~kg}$ of dry plant biomass was applied and accordingly $0.24 \mathrm{~kg}$ of earthworm was inoculated that approximately equals to inoculation of 500 nos. of E. fetida in their respective treatments/pit. Water was sprinkled immediately after the release of earthworms. The CDM used in the present investigation was Pseudomonas sp. 
which was being maintained for purity through sub-culturing. Mass cultivation was done by inoculating the strain in $500 \mathrm{ml}$ Erlenmeyer flasks containing $250 \mathrm{ml}$ of potato dextrose broth (PDB) followed by incubation in BOD shaking incubator with periodic shaking at $250 \mathrm{rpm}$ under optimum culture conditions for growth and improved metabolite production. After the incubation period was over, $5 \%(\mathrm{v} / \mathrm{v})$ cell suspension of Pseudomonas sp. (approx. $12 \times 10^{8} \mathrm{cfu} \mathrm{ml}^{-1}$ ) was mixed with plant biomass for bioconversion. 50-60\% moisture level was maintained during the biodegradation process. A temporary bamboo shed was prepared over the composing unit for protection against the accumulation of excessive water in the rainy season. The organic materials undergoing bioconversion were carefully turned every 7 days for better aeration. Organic waste decomposition was ensured after change in odor and weight loss of the compost during bioconversion. Gautam et al. (2012) was followed to measure the percent loss of the finished product. After 3 months of composting, the decomposed plant biomass was harvested and kept over a heap of partially decomposed cow dung as to facilitate the worm species to migrate into the cow dung from the compost. The compost was separated and sieved for use. Compost recovery percentage, nutrient contents, viz., $\mathrm{pH}$, nitrogen, phosphorus, potassium, organic carbon and enzyme activity (cellulase) and bacterial and fungal populations including those likes cellulose degraders, phosphate solubilizers and nitrogen fixers of the compost were analyzed, further, to screen out the possible alternatives for cost-effective and easy decomposition of plant biomass into quality organic manure. An electrical digital $\mathrm{pH}$ meter was used to determine the $\mathrm{pH}$ of the compost. Organic carbon was determined in accordance with Walkley and Black (1934) using the wet digestion method. Gupta et al. (2011) was followed to measure the cellulase activity. Alkaline $\mathrm{KMnO}_{4}$ distillation technique as advised by Subbiah and Asija (1956) was used to estimate the available N, while the Bray-I method (Bray and Kurtz 1945) and ammonium acetate extraction followed by emission spectrometry (Jackson 1962) was followed to determine the available $\mathrm{P}$ and $\mathrm{K}$, respectively.

\section{Field application}

Different treatments of bioconversion (vermicompost) were applied in the field to observe and record their efficacy in increasing productivity of groundnut as well as to improve the soil health in the terrace land situation of Meghalaya. Soil nutrient status of the experimental field was acidic (pH: 4.8) with $2.0 \%$ organic carbon, $268,14.6$ and $115 \mathrm{~kg} \mathrm{ha}^{-1}$ of $\mathrm{N}, \mathrm{P}_{2} \mathrm{O}_{5}$ and $\mathrm{K}_{2} \mathrm{O}$, respectively. Treatments comprised the recommended dose of fertilizer (RDF), i.e., 20,60 , and $40 \mathrm{~kg} \mathrm{ha}^{-1}$ of $\mathrm{N}, \mathrm{P}_{2} \mathrm{O}_{5}$ and $\mathrm{K}_{2} \mathrm{O}$, respectively. Five treatments such as $50 \% \mathrm{RDF}+$ vermicompost
$(\mathrm{PB}+\mathrm{CD}) 2.5 \mathrm{t} \mathrm{ha}^{-1}, 50 \% \mathrm{RDF}+$ vermicompost (PB + CD + EW) $2.5 \mathrm{t} \mathrm{ha}^{-1}, 50 \% \mathrm{RDF}+$ vermicompost $(\mathrm{PB}+\mathrm{CD}+\mathrm{EW}+\mathrm{WPL}) 2.5 \mathrm{tha}^{-1}, 50 \% \mathrm{RDF}+$ vermicompost $(\mathrm{PB}+\mathrm{CD}+\mathrm{EW}+\mathrm{CDM}) 2.5 \mathrm{tha}^{-1}$ and $50 \% \mathrm{RDF}+$ vermicompost $(\mathrm{PB}+\mathrm{CD}+\mathrm{EW}+\mathrm{CDM}+\mathrm{WPL}) 2.5 \mathrm{tha}^{-1}$ were designed throughout the experiment. Application of fertilizer was made in the form of urea, single super phosphate (SSP) and muriate of potash (MOP), respectively. Groundnut (var. ICGS 76) was sown at an interval of $20 \mathrm{~cm}$ differences between the rows. A randomized block design (RBD) with four replications was used for treatment application. Groundnut seeds were sown during June and harvested in September. The yield and yield components were recorded during the harvesting period. Soil samples of the post-harvest soil were collected from each plot $(0-20 \mathrm{~cm}$ depth), air dried and sieved through $2.0 \mathrm{~mm}$ sieve. The sample analysis for different soil parameters, viz, $\mathrm{pH}$, organic carbon, available $\mathrm{N}, \mathrm{P}$ and $\mathrm{K}$ was made in accordance with standard protocol as mentioned above.

\section{Data analysis}

Least significant difference (LSD), standard error mean (SEM), degrees of freedom (n) among different treatments were calculated in accordance with Gomez and Gomez (1984). Tukey's post hoc test was carried out to explain the honestly significant difference among different treatments. Values within the same column followed by different letters are significantly different $(P=0.05)$ from each other. The correlation coefficient among different quality parameters of the compost was determined using IBM SPSS Statistics.

\section{Results and discussion}

A total of 14 bacterial strains were isolated on cellulose agar media. The bacteria when subjected for cellulose-degrading potential, only one out of fourteen showed potent activity on cellulose Congo red media, causing discolouration of Congo red. Using biochemical test methods, as mentioned in the methodology section, the potent strain was characterized as Pseudomonas sp. In the present investigation, Pseudomonas sp. showed maximum cellulose-degrading potential as compared to other isolated strains. Pathogenicity test for the microbe when conducted using media like EMB agar and MCA, the bacteria were unable to grow in these selective media, thus, indicating its suitability for use in an agricultural perspective. Microbial enrichment of compost with inoculation of biological agent was earlier studied by Fitriatin et al. (2016) and thereby brought new perspectives about the application of biofertilizer in agriculture.

During the experimentation, plant biomass was converted into quality organic manure within a period of 3 months. 
Decomposition of organic residues might assist in nutrient release and thereby make them available for the use of living organisms (Mahanta et al. 2012b). Compost recovery percentage was maximum in the treatment applied with earthworm and CDM with poly lining in the pit (69.1\%) followed by earthworm and CDM without poly lining (67.5\%) over untreated control (53.2\%). Results of Tukey's post hoc test revealed that this treatment showed honest significant difference in terms of compost recovery and other nutrient content (Table 2) over control. The phenomenon might be due to the key role played by earthworms in hastening the rate of organic waste decomposition, as they have the tendency to feed decomposing plant biomass and thereby prepare the surface area for effective colonization of CDM. Bityutskii et al. (2007) have indicated that the acceleration in nitrogen mineralization process is due to organic matter decomposition by earthworm. The CDMs are also known for their expertise in utilizing the complex cellulose materials for their energy source and thereby effectively attributing to the improvement in the quality of compost (Barman et al. 2011). The present findings are in accordance with Yadav et al. (2013) who too reported the potentiality of worm species in accelerating organic matter decomposition. Composting efficiency of earthworm and CDM was also reported by Mahanta et al. (2012a) and thereby indicated the ability of biological agents in degrading the cellulose. There was an enhancement in compost nutrient content due to poly lining in the pit that avoided leaching during the process of composting (Khan and Sharif 2012). Hobara et al. (2013) reported the role of microorganisms in building a renewable source of energy through utilization of organic residues. Bioconversion of agricultural waste with sustainable approaches, thus, creates opportunities for the environmental scientists to develop quality organic manure that is necessary for enhancing crop productivity and improving soil nutrition.

The beneficial microbial population numbers (bacteria and fungi) and functional microbial categories like cellulose degraders, phosphate solubilizers and nitrogen fixers were highest in the dual inoculation treatment of earthworm and CDM with poly lining in the pit (bacterial population, $278.7 \times 10^{6} \mathrm{cfu} \mathrm{g}^{-1}$; fungal population, $4.0 \times 10^{6} \mathrm{cfu} \mathrm{g}^{-1}$; cellulose-degrading bacteria, $68.7 \times 10^{6} \mathrm{cfu} \mathrm{g}^{-1}$; phosphatesolubilizing bacteria, $59.5 \times 10^{6} \mathrm{cfu} \mathrm{g}^{-1}$; nitrogen-fixing bacteria, $\left.54.5 \times 10^{6} \mathrm{cfu} \mathrm{g}^{-1}\right)$. Honest significant difference in terms of microbial population was observed among the treatments as per Tukey's post hoc test analysis. Dual inoculation of earthworm and CDM with poly lining in the pit showed significant improvement in establishment of higher microbial populations as compared to other treatments (Table 3). The biological agents (earthworm and CDM) might create an environment suitable for higher microbial growth.

Pearson's correlation coefficient of the quality parameters of compost in different treatments is presented in Table 4. The correlation matrix of 12 quality parameters showed significant correlations among 58 of the 66 quality parameter pairs $(P=0.05$ and $P=0.01)$ which reflect the tendency of different properties of compost to respond in group when subjected to different practices.

The yield and yield attributing components of groundnut were also significantly influenced due to vermicomposting (Table 5). Plant height, dry weight of the plant, root dry weight, pod/plant, seed/pod and test weight (10 pod seed weight) ranged from 53.1 to $58.7 \mathrm{~cm}, 13.3$ to $18.3 \mathrm{~g}, 5.0$ to $6.2 \mathrm{~g}, 15.3$ to 21.1 (in nos.), 21.7 to 25.4 (in nos.) and 7.9 to $11.8 \mathrm{~g}$, respectively. The treatment receiving 50\% RDF in combination with vermicompost $(\mathrm{PB}+\mathrm{CD}+\mathrm{EW}+\mathrm{CDM}+\mathrm{WPL}) 2.5 \mathrm{t} \mathrm{ha}^{-1}$ exhibited maximum pod and stover yield (17.6 and $53.3 \mathrm{q} \mathrm{ha}^{-1}$, respectively) of groundnut followed by the treatment RDF alone. Moreover, results of Tukey's post hoc test showed significant differences among the treatments in term of yield and yield attributes (Table 5). Increase in pod yield might be due to improvement in yield components following integrated use of $50 \% \mathrm{RDF}+$ vermicompost $(\mathrm{PB}+\mathrm{CD}+\mathrm{EW}+\mathrm{CDM}+\mathrm{WPL})$. Increased and prolonged availability of nutrients, improvement

Table 2 Compost recovery percent, nutrient content and enzyme activity under bioconversion

\begin{tabular}{|c|c|c|c|c|c|c|c|c|}
\hline Treatments & $\begin{array}{l}\text { Compost } \\
\text { recovery }(\%)\end{array}$ & $\mathrm{pH}$ & $\begin{array}{l}\text { Organic } \\
\text { carbon }(\%)\end{array}$ & $\mathrm{N}(\%)$ & $\mathrm{C}: \mathrm{N}$ ratio & $\mathrm{P}_{2} \mathrm{O}_{5}(\%)$ & $\mathrm{K}_{2} \mathrm{O}(\%)$ & $\begin{array}{l}\text { Cellulase } \\
\left(\mathrm{IU} \mathrm{ml^{-1 }}\right)\end{array}$ \\
\hline $\mathrm{PB}+\mathrm{CD}$ (control) & $53.2 \mathrm{a}$ & $5.5 \mathrm{a}$ & $18.6 \mathrm{a}$ & $0.88 \mathrm{a}$ & $21.1 \mathrm{a}$ & $0.33 \mathrm{a}$ & $1.09 \mathrm{a}$ & $2.86 a$ \\
\hline $\mathrm{PB}+\mathrm{CD}+\mathrm{EW}$ & $62.3 \mathrm{bc}$ & $6.0 \mathrm{ab}$ & $20.1 \mathrm{a}$ & $1.02 \mathrm{ab}$ & $19.7 \mathrm{a}$ & $0.35 \mathrm{ab}$ & $1.10 \mathrm{a}$ & $3.04 \mathrm{a}$ \\
\hline $\mathrm{PB}+\mathrm{CD}+\mathrm{EW}+\mathrm{WPL}$ & $57.3 \mathrm{ab}$ & $6.4 \mathrm{~b}$ & $20.8 \mathrm{ab}$ & $1.09 \mathrm{bc}$ & $19.0 \mathrm{a}$ & $0.39 \mathrm{ab}$ & $1.12 \mathrm{a}$ & $3.51 \mathrm{ab}$ \\
\hline $\mathrm{PB}+\mathrm{CD}+\mathrm{EW}+\mathrm{CDM}$ & $67.5 \mathrm{c}$ & $5.5 \mathrm{a}$ & $24.1 b c$ & $1.13 b c$ & $21.3 \mathrm{a}$ & $0.45 \mathrm{ab}$ & $1.14 \mathrm{a}$ & $3.79 \mathrm{ab}$ \\
\hline $\mathrm{PB}+\mathrm{CD}+\mathrm{EW}+\mathrm{CDM}+\mathrm{WPL}$ & $69.1 \mathrm{c}$ & $5.6 \mathrm{a}$ & $26.6 \mathrm{c}$ & $1.24 \mathrm{c}$ & $21.5 \mathrm{a}$ & $0.53 b$ & $1.15 \mathrm{a}$ & $4.44 \mathrm{~b}$ \\
\hline $\operatorname{SEM}( \pm)$ & 1.08 & 0.08 & 0.44 & 0.02 & 0.34 & 0.02 & 0.01 & 0.12 \\
\hline $\operatorname{LSD}(P=0.05)$ & 3.15 & 0.22 & 1.27 & 0.06 & 0.98 & 0.06 & 0.02 & 0.36 \\
\hline
\end{tabular}

$P B$ plant biomass, $C D$ cow dung, $E W$ earthworm, $C D M$ cellulose-degrading microorganism, $W P L$ with poly lining

Different letters in the same column indicate significant differences by Tukey's post hoc test at $P=0.05(n=24)$ 
Table 3 Analysis for microbial populations of the compost under different treatments of bioconversion

\begin{tabular}{|c|c|c|c|c|c|}
\hline Treatments & $\begin{array}{l}\text { Cellulose-degrading bac- } \\
\text { teria }\left(\mathrm{cfu} \times 10^{6} \mathrm{~g}^{-1}\right)\end{array}$ & $\begin{array}{l}\text { Phosphate-solubilizing } \\
\text { bacteria }\left(\mathrm{cfu} \times 10^{6} \mathrm{~g}^{-1}\right)\end{array}$ & $\begin{array}{l}\text { Nitrogen-fixing bacteria } \\
\left(\mathrm{cfu} \times 10^{6} \mathrm{~g}^{-1}\right)\end{array}$ & $\begin{array}{l}\text { Total bacterial popula- } \\
\text { tion }\left(\mathrm{cfu} \times 10^{6} \mathrm{~g}^{-1}\right)\end{array}$ & $\begin{array}{l}\text { Total fungal population } \\
\left(\mathrm{cfu} \times 10^{6} \mathrm{~g}^{-1}\right)\end{array}$ \\
\hline $\mathrm{PB}+\mathrm{CD}$ (control) & $33.5 \mathrm{a}$ & $34.5 \mathrm{a}$ & $29.5 \mathrm{a}$ & $113.2 \mathrm{a}$ & $1.9 \mathrm{a}$ \\
\hline $\mathrm{PB}+\mathrm{CD}+\mathrm{EW}$ & $49.5 b$ & $47.5 b$ & $39.3 b$ & $177.7 \mathrm{~b}$ & $2.5 \mathrm{ab}$ \\
\hline $\mathrm{PB}+\mathrm{CD}+\mathrm{EW}+\mathrm{WPL}$ & $35.6 \mathrm{a}$ & $33.7 \mathrm{a}$ & $30.0 \mathrm{a}$ & $129.0 \mathrm{a}$ & $2.2 \mathrm{ab}$ \\
\hline $\mathrm{PB}+\mathrm{CD}+\mathrm{EW}+\mathrm{CDM}$ & $64.2 \mathrm{c}$ & $58.5 \mathrm{c}$ & $52.2 \mathrm{c}$ & $227.5 \mathrm{c}$ & $2.9 \mathrm{~b}$ \\
\hline $\mathrm{PB}+\mathrm{CD}+\mathrm{EW}+\mathrm{CDM}+\mathrm{WPL}$ & $68.7 \mathrm{c}$ & $59.5 \mathrm{c}$ & $54.5 \mathrm{c}$ & $278.7 d$ & $4.0 \mathrm{c}$ \\
\hline $\operatorname{SEM}( \pm)$ & 0.81 & 0.87 & 1.14 & 3.17 & 0.10 \\
\hline $\operatorname{LSD}(P=0.05)$ & 2.35 & 2.53 & 3.32 & 9.23 & 0.28 \\
\hline
\end{tabular}

$P B$ plant biomass, $C D$ cow dung, $E W$ earthworm, $C D M$ cellulose-degrading microorganism, $W P L$ with poly lining

Different letters in the same column indicate significant differences by Tukey's post hoc test at $P=0.05(n=24)$

in soil physical properties as well as biological activity due to the use of vermicompost might have resulted in increased plant growth and other yield-related parameters. According to Pathma and Sakthivel (2012), vermicompost has the ability to enhance soil biodiversity through promoting the beneficial plant-microbe interaction. Combined application of $50 \%$ RDF with vermicompost $(\mathrm{PB}+\mathrm{CD}+\mathrm{EW}+\mathrm{CDM}+\mathrm{WPL}) 2.5 \mathrm{t} \mathrm{ha}^{-1}$ resulted in significantly higher nutrient build up in soil even after harvesting followed by the treatment receiving RDF alone. Moreover, $\mathrm{N}, \mathrm{P}_{2} \mathrm{O}_{5}$ and $\mathrm{K}_{2} \mathrm{O}$ were significantly higher among the other treatments as per the statistical analysis (Table 6). This might be due to prolonged availability of nutrients' release from vermicompost resulting in higher biological activity that subsequently leads to enhanced mineralization in soil. The available $\mathrm{P}_{2} \mathrm{O}_{5}$ in soil ranged from $20.8-25.2 \mathrm{~kg} \mathrm{ha}^{-1}$, being highest in the treatment receiving 50\% RDF along with vermicompost $(\mathrm{PB}+\mathrm{CD}+\mathrm{EW}+\mathrm{CDM}+\mathrm{WPL}) 2.5 \mathrm{tha}^{-1}$ followed by the treatment RDF alone. The results are in accordance with Rajkhowa et al. (2017). Vermicompost rich in phosphorus $(1.2 \%)$ might have added the adequate quantity of phosphorus in soil through release of various organic acids. The available $\mathrm{K}_{2} \mathrm{O}$ in soil also varied significantly due to nutrient management practices that ranged from 126.9 to $141 \mathrm{~kg} \mathrm{ha}^{-1}$. Application of vermicompost might have resulted in better mineralization of native soil nutrients through creation of healthy environmental practices. Improvement in soil nutrient status due to combined application of vermicompost and 50\% RDF was reported by Rajkhowa et al. (2017). Integrated use of 50\% RDF with vermicompost $(\mathrm{PB}+\mathrm{CD}+\mathrm{EW}+\mathrm{CDM}+\mathrm{WPL})$ $2.5 \mathrm{tha}^{-1}$ also significantly improved the soil organic carbon $(2.48 \%)$ as compared to the treatment receiving RDF alone $(2.46 \%)$. Soil $\mathrm{pH}$ was maximum with the treatment receiving 50\% RDF along with vermicompost $(\mathrm{PB}+\mathrm{CD}+\mathrm{EW}+\mathrm{CDM}+\mathrm{WPL}) 2.5 \mathrm{tha}^{-1}$. Increase in soil $\mathrm{pH}$ might be due to application of organic fertilizer, as the latter tends to increase soil $\mathrm{pH}$ by supplying bases, forming alkaline humates during decomposition.

\section{Conclusion}

Efficient bioconversion of agricultural waste into quality organic manure is of immense importance in the present decade to develop an eco-friendly and sustainable approach in agriculture. The results of the present investigation exposed the dual inoculation effect of E. fetida (a potent earthworm species) and Pseudomonas sp. (CDM) with poly lining in the pit as a suitable approach for safe and faster decomposition and effective bioconversion of agricultural waste into quality organic manure in the hilly ecosystem of Northeast India. Application of such organic manure has, also, proven its potential in increasing crop yield as well as improving soil health. 


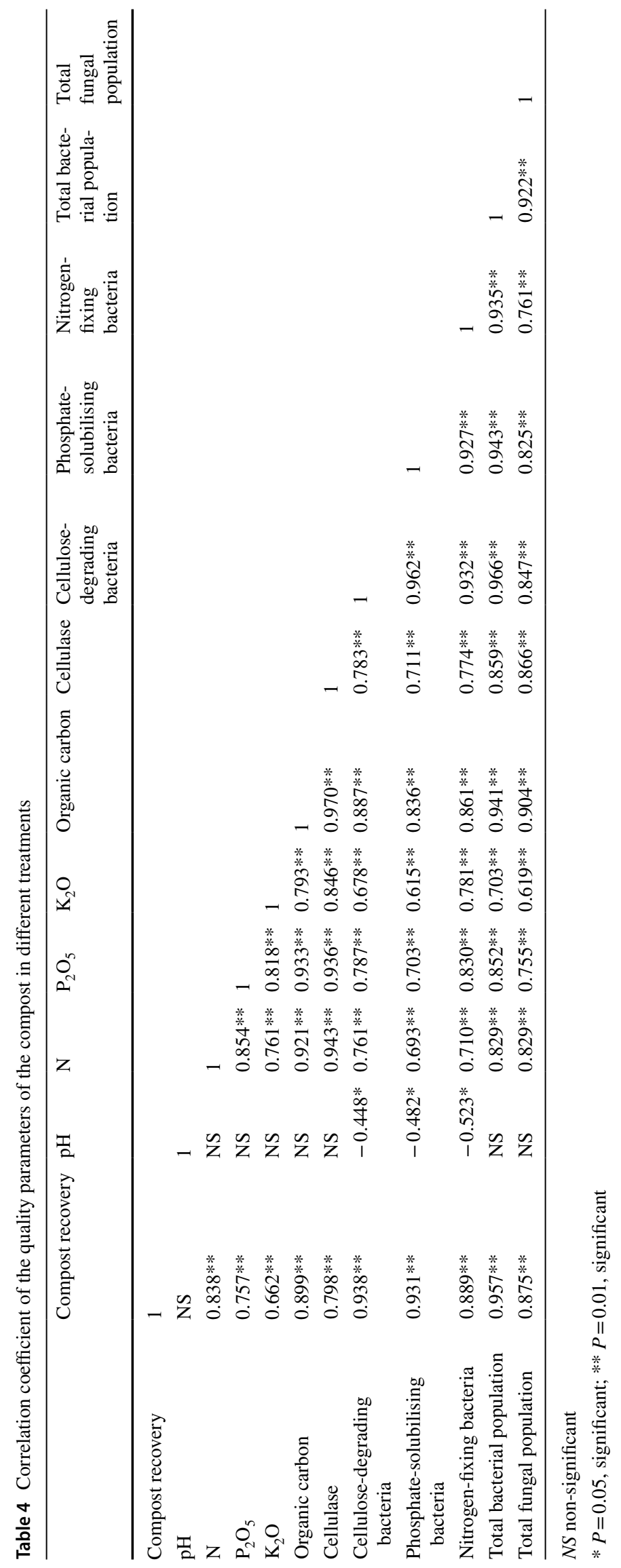


Table 5 Yield and yield attributes of groundnut under different treatments of vermicompost

\begin{tabular}{|c|c|c|c|c|c|c|c|c|}
\hline Treatment & Plant height $(\mathrm{cm})$ & $\begin{array}{l}\text { Plant dry } \\
\text { weight } \\
\text { (g) }\end{array}$ & $\begin{array}{l}\text { Root dry } \\
\text { weight } \\
\text { (g) }\end{array}$ & Pod plant ${ }^{-1}$ & Seed pod $^{-1}$ & $\begin{array}{l}\text { Ten pod } \\
\text { seed weight } \\
\text { (g) }\end{array}$ & $\begin{array}{l}\text { Pod yield } \\
\left(\mathrm{q} \mathrm{ha}^{-1}\right)\end{array}$ & $\begin{array}{l}\text { Stover } \\
\text { yield (q } \\
\left.\mathrm{ha}^{-1}\right)\end{array}$ \\
\hline $\begin{array}{l}\text { Recommended dose of fertilizer } \\
\text { (RDF) }\end{array}$ & $57.4 \mathrm{a}$ & $17.6 \mathrm{~b}$ & $5.8 \mathrm{ab}$ & $20.6 a b$ & $2.48 \mathrm{a}$ & $11.2 \mathrm{~cd}$ & $16.8 \mathrm{a}$ & $52.0 \mathrm{c}$ \\
\hline $50 \% \mathrm{RDF}+$ vermicompost $(\mathrm{PB}+\mathrm{CD})$ & $53.1 \mathrm{a}$ & $13.3 \mathrm{a}$ & $5.0 \mathrm{a}$ & $15.3 \mathrm{a}$ & $2.17 \mathrm{a}$ & $7.9 \mathrm{a}$ & $14.8 \mathrm{a}$ & $42.9 \mathrm{a}$ \\
\hline $\begin{array}{l}50 \% \text { RDF + vermicompost } \\
(\mathrm{PB}+\mathrm{CD}+\mathrm{EW})\end{array}$ & $54.2 \mathrm{a}$ & $14.4 \mathrm{ab}$ & $5.2 \mathrm{a}$ & $16.4 \mathrm{ab}$ & $2.30 \mathrm{a}$ & $8.6 \mathrm{ab}$ & $15.6 \mathrm{a}$ & $46.6 \mathrm{ab}$ \\
\hline $\begin{array}{c}50 \% \mathrm{RDF}+\text { vermicompost } \\
(\mathrm{PB}+\mathrm{CD}+\mathrm{EW}+\mathrm{WPL})\end{array}$ & $55.1 \mathrm{a}$ & $15.0 \mathrm{ab}$ & $5.3 \mathrm{a}$ & $18.7 \mathrm{ab}$ & $2.39 \mathrm{a}$ & $9.6 \mathrm{abc}$ & $16.0 \mathrm{a}$ & $48.8 b c$ \\
\hline $\begin{array}{r}50 \% \mathrm{RDF}+\text { vermicompost } \\
(\mathrm{PB}+\mathrm{CD}+\mathrm{EW}+\mathrm{CDM})\end{array}$ & $56.6 \mathrm{a}$ & $16.6 a b$ & $5.5 \mathrm{ab}$ & $20.0 \mathrm{ab}$ & $2.45 a$ & $9.9 \mathrm{bc}$ & $16.2 \mathrm{a}$ & $51.6 b c$ \\
\hline $\begin{array}{l}50 \% \text { RDF + vermicompost } \\
(\mathrm{PB}+\mathrm{CD}+\mathrm{EW}+\mathrm{CDM}+\mathrm{WPL})\end{array}$ & $58.7 \mathrm{a}$ & $18.3 b$ & $6.2 \mathrm{~b}$ & $21.0 \mathrm{~b}$ & $2.54 \mathrm{a}$ & $11.8 \mathrm{~d}$ & $17.6 \mathrm{a}$ & $53.3 \mathrm{c}$ \\
\hline $\operatorname{SEM}( \pm)$ & 0.84 & 0.54 & 0.08 & 0.59 & 0.11 & 0.25 & 0.33 & 0.73 \\
\hline $\operatorname{LSD}(P=0.05)$ & 2.45 & 1.56 & 0.24 & 1.71 & 0.32 & 0.74 & 0.95 & 2.12 \\
\hline
\end{tabular}

$P B$ plant biomass, $C D$ cow dung, $E W$ earthworm, $C D M$ cellulose-degrading microorganism, $W P L$ with poly lining

Different letters in the same column indicate significant differences by Tukey's post hoc test at $P=0.05(n=23)$

Table 6 Nutrient status in the post-harvest soil under different treatments of vermicompost

\begin{tabular}{|c|c|c|c|c|c|}
\hline \multirow[t]{2}{*}{ Treatment } & \multirow[t]{2}{*}{$\mathrm{pH}$} & \multicolumn{3}{|c|}{ Nutrient content $\left(\mathrm{kg} \mathrm{ha}^{-1}\right)$} & \multirow{2}{*}{$\begin{array}{l}\text { Soil organic } \\
\text { carbon }(\%)\end{array}$} \\
\hline & & $\mathrm{N}$ & $\mathrm{P}_{2} \mathrm{O}_{5}$ & $\mathrm{~K}_{2} \mathrm{O}$ & \\
\hline Recommended dose of fertilizer (RDF) & $4.86 \mathrm{a}$ & $286.2 \mathrm{a}$ & $24.5 \mathrm{bc}$ & $140.2 \mathrm{c}$ & $2.46 \mathrm{a}$ \\
\hline $50 \% \mathrm{RDF}+$ vermicompost $(\mathrm{PB}+\mathrm{CD})$ & $4.72 \mathrm{a}$ & $275.9 \mathrm{a}$ & $20.8 \mathrm{a}$ & $126.9 \mathrm{a}$ & $2.28 \mathrm{a}$ \\
\hline $50 \% \mathrm{RDF}+$ vermicompost $(\mathrm{PB}+\mathrm{CD}+\mathrm{EW})$ & $4.78 \mathrm{a}$ & $278.8 \mathrm{a}$ & $21.2 \mathrm{ab}$ & $132.0 \mathrm{ab}$ & $2.36 \mathrm{a}$ \\
\hline $50 \% \mathrm{RDF}+$ vermicompost $(\mathrm{PB}+\mathrm{CD}+\mathrm{EW}+\mathrm{WPL})$ & $4.80 \mathrm{a}$ & $280.2 \mathrm{a}$ & $22.6 \mathrm{ab}$ & $137.8 \mathrm{bc}$ & $2.40 \mathrm{a}$ \\
\hline $50 \% \mathrm{RDF}+$ vermicompost $(\mathrm{PB}+\mathrm{CD}+\mathrm{EW}+\mathrm{CDM})$ & $4.82 \mathrm{a}$ & $283.6 \mathrm{a}$ & $23.8 \mathrm{abc}$ & $138.4 \mathrm{bc}$ & $2.42 \mathrm{a}$ \\
\hline $50 \% \mathrm{RDF}+$ vermicompost $(\mathrm{PB}+\mathrm{CD}+\mathrm{EW}+\mathrm{CDM}+\mathrm{WPL})$ & $4.95 \mathrm{a}$ & $290.8 \mathrm{a}$ & $26.2 \mathrm{c}$ & $142.0 \mathrm{c}$ & $2.48 \mathrm{a}$ \\
\hline $\operatorname{SEM}( \pm)$ & 0.25 & 1.97 & 0.43 & 1.17 & $0.08 \mathrm{a}$ \\
\hline $\operatorname{LSD}(P=0.05)$ & 0.72 & 5.74 & 1.24 & 3.40 & $0.22 \mathrm{a}$ \\
\hline
\end{tabular}

$P B$ plant biomass, $C D$ cow dung, $E W$ earthworm, $C D M$ cellulose-degrading microorganism, $W P L$ with poly lining

Different letters in the same column indicate significant differences by Tukey's post hoc test at $P=0.05(n=23)$

Acknowledgements The authors are thankful to the Director, ICAR Research Complex for NEH Region, Umiam, Meghalaya, India for providing the necessary facilities to carry out this research.

\section{Compliance with ethical standards}

Conflict of interest The authors declare that there is no conflict of interest.

Open Access This article is distributed under the terms of the Creative Commons Attribution 4.0 International License (http://creativecommons.org/licenses/by/4.0/), which permits unrestricted use, distribution, and reproduction in any medium, provided you give appropriate credit to the original author(s) and the source, provide a link to the Creative Commons license, and indicate if changes were made.

\section{References}

Anderson JM, Ingram JSI (1993) Tropical soil biology and fertility, 2nd edn. Cab International, Wallingford

Ansari AA (2010) Indigenous approach in organic solid waste management in Guyana (South America). KUSET 6:54-59. https://doi. org/10.3126/kuset.v6i2.4012

Barman D, Saud ZA, Habib MR, Islam MF, Hossain K, Yeasmin T (2011) Isolation of cellulolytic bacterial strains from soil for effective and efficient bioconversion of solid waste. Life Sci Med Res 25:1-10

Bityutskii NP, Soloveva AN, Lukina EI, Oleinik AS, Zavgorodnyaya YA, Demin VV, Byzov BA (2007) Stimulating effect of earthworm excreta on the mineralization of nitrogen compounds in soil. Eurasian Soil Sci 40:426-431. https://doi.org/10.1134/S1064 229307040096

Bray RH, Kurtz LT (1945) Determination of total, organic and available forms of phosphorus in soils. Soil Sci 59:39-45 
Cappucino JG, Sherman N (2004) Microbiology: a laboratory manual, 7 th edn. Pearson Education, London

Edwards CA, Bohlen PJ (1996) Biology and ecology of earthworms, 3rd edn. Chapman and Hall, London

Fitriatin BN, Simarmata T, Hersanti, Tienturmuktini (2016) Straw composting with biological agent inoculation and application biofertilizer to increase rice production. Int J Sustain Agric Res 3:49-53. https://doi.org/10.18488/journal.70/2016.3.3/70.3.49.53

Gautam SP, Bundela PS, Pandey AK, Jamaluddin Awasthi MK, Sarsaiya S (2012) Diversity of cellulolytic microbes and the biodegradation of municipal solid waste by a potential strain. Int $\mathrm{J}$ Microbiol. https://doi.org/10.1155/2012/325907

Gomez KA, Gomez AA (1984) Statistical procedures for agricultural research. Wiley, New York

Gupta R, Khasa YP, Kuhad RC (2011) Evaluation of pretreatment methods in improving the enzymatic saccharification of cellulosic materials. Carbohydr Polym 84:1103-1109. https://doi. org/10.1016/j.carbpol.2010.12.074

Gupta P, Samant K, Sahu A (2012) Isolation of cellulose-degrading bacteria and determination of their cellulolytic potential. Int $\mathrm{J}$ Microbiol. https://doi.org/10.1155/2012/578925

Hazarika UK, Munda GC, Bujarbaruah KM, Das A, Patel DP, Prasad K, Rajesh Kumar, Panwar AS, Tomar JMS, Bordoloi J, Sharma M, Gogoi G (2006) Nutrient management in organic farming. Technical Bulletin no. 30, ICAR Research Complex for NEH Region, Umiam, Meghalaya, India

Hobara S, Osono T, Hirose D, Noro K, Hirota M, Banner R (2013) The roles of microorganisms in litter decomposition and soil formation. Biogeochemistry 118:471-486. https://doi. org/10.1007/s10533-013-9912-7

Holt JG, Krieg NR, Sneath PHA, Staley JT, Williams ST (1994) Bergey's manual of determinative bacteriology, 9th edn. Lippincott Williams and Wilkins, Philadelphia

Indian Fertilizer Scenario (2010) Department of fertilizer. Ministry of Chemical and Fertilizers, Government of India

Jackson ML (1962) Soil chemical analysis. Prentice Hall of India Pvt. Ltd., New Delhi

Kato S, Haruta S, Cui ZJ, Ishii M, Igarashi Y (2004) Effective cellulose degradation by a mixed-culture system composed of a cellulolytic Clostridium and aerobic noncellulolytic bacteria. FEMS Microbiol Ecol 51:133-142. https://doi.org/10.1016/j.femse c. 2004.07.015

Khan M, Sharif M (2012) Solubility enhancement of phosphorus from rock phosphate through composting with poultry litter. Sarhad J Agric 28:415-420

Lu WJ, Wang HT, Nie YF, Wang ZC, Huang DY, Qiu XY, Chen JC (2004) Effect of inoculating flower stalks and vegetable waste with ligno-cellulolytic microorganisms on the composting process. J Environ Sci Health B 39:871-887

Mahanta K, Jha DK, Rajkhowa DJ (2012a) Effect of cellulolytic bioinoculants and their co-inoculation with earthworm on the conversion of plant biomass. J Crop Weed 8:47-51

Mahanta K, Jha DK, Rajkhowa DJ, Manoj-Kumar (2012b) Microbial enrichment of vermicompost prepared from different plant biomasses and their effect on rice (Oryza sativa L.) growth and soil fertility. Biol Agric Hort 28:241-250. https://doi. org/10.1080/01448765.2012.738556

Mandels M, Reese ET (1999) Fungal cellulases and the microbial decomposition of cellulosic fabric. J Ind Microbiol Biotechnol $22: 225-240$

Molina MJ, Soriano MD, Ingelmo F, Linares J (2013) Stabilisation of sewage sludge and vinasse bio-wastes by vermicomposting with rabbit manure using Eisenia fetida. Bioresour Technol 137:88-97. https://doi.org/10.1016/j.biortech.2013.03.029

Monroy F, Aira M, Dominguez J (2009) Reduction of total coliform numbers during vermicomposting is caused by short term direct effects of earthworms on microorganisms and depends on the dose of application of pig slurry. Sci Total Environ 407:5411-5416. https://doi.org/10.1016/j.scitotenv.2009.06.048

Moral R, Paredes C, Bustamante MA, Marhuenda-Egea R, Bernal MP (2009) Utilisation of manure composts by high-value crops: safety and environmental challenges. Bioresour Technol 100:5454-5460. https://doi.org/10.1016/j.biortech.2008.12.007

Pathma J, Sakthivel N (2012) Microbial diversity of vermicompost bacteria that exhibit useful agricultural traits and waste management potential. SpringerPlus 1:26. https://doi. org/10.1186/2193-1801-1-26

Rajkhowa DJ, Borah D (2008) Effect of rice (Oryza sativa) straw management on growth and yield of wheat (Triticum aestivum). Indian J Agron 53:112-115

Rajkhowa DJ, Manoj-Kumar (2013) Biowaste utilization for improving health and productivity of acid soils in North East India. Curr Sci 104:11-12

Rajkhowa DJ, Bhattacharyya PN, Sarma AK, Mahanta K (2015) Diversity and distribution of earthworms in different soil habitats of Assam, North-East India, an Indo-Burma Biodiversity Hotspot. Proc NASI Sec B Biol Sci 85:389-396. https://doi.org/10.1007/ s40011-014-0380-1

Rajkhowa DJ, Sarma AK, Mahanta K, Saikia US, Krishnappa R (2017) Effect of vermicompost on green gram productivity and soil health under hilly ecosystem of North East India. J Environ Biol 38:1519. https://doi.org/10.22438/jeb/38/1/MS-114

Raphael K, Velmourougane SK (2012) Vermicomposting of coffee processing wastes using exotic (Eudrilus Eugeniae) and native earthworm (Perionyx ceylanesis) species. Macromol Symp 320:61-69. https://doi.org/10.1002/masy.201251008

Rousseau GX, dos Santos Silva PR, de Carvalho CJR (2010) Earthworms, ants and other arthropods as soil health indicators in traditional and no-fire agro-ecosystems from eastern Brazilian Amazonia. Acta Zool Mex 2:117-134

Singh MD, Jagadeesh KS (2009) Use of composted eupatorium as a source of nutrients for groundnut. Karnataka J Agric Sci 22:190-191

Sinha RK (2009) Earthworms vermicompost: a powerful crop nutrient over the conventional compost \& protective soil conditioner against the destructive chemical fertilizers for food safety and security. Am Euras J Agric Environ Sci 5:51-55

Subbiah BV, Asija GL (1956) A rapid procedure for the estimation of available nitrogen in soils. Curr Sci 25:259-260

Tondoh EJ, Lavelle P (2005) Population dynamics of Hyperiodrilus africanus (Oligochaeta, Eudrilidae) in Ivory Coast. J Trop Ecol 21:493-500. https://doi.org/10.1017/S0266467405002506

Tripathi RS, Barik SK (2003) Shifting cultivation in North East India. In: Proceedings on approach for increasing agricultural productivity in hill und mountain ecosystem. ICAR Research Complex for NEH Region, Umiam, Meghalaya, India

Walkley A, Black IA (1934) An examination of the Degtjareff method for determining soil organic matter and proposed modification of the chromic acid titration method. Soil Sci 37:29-38

Yadav A, Gupta R, Garg VK (2013) Organic manure production from cow dung and biogas plant slurry by vermicomposting under field conditions. Int J Recycl Org Waste Agric 2:21. https://doi. org/10.1186/2251-7715-2-21

Publisher's Note Springer Nature remains neutral with regard to jurisdictional claims in published maps and institutional affiliations. 